\title{
HOW IT STARTS AND ENDS: A STUDY OF INDONESIAN STAND-UP COMEDY
}

\author{
Lia Afidah ${ }^{1)}$ \\ Ribut Wahyudi ${ }^{2}$ \\ ${ }^{1)}$ School of English Language and Letters, \\ Maulana Malik Ibrahim State Islamic University, Indonesia \\ E-mail: cloverlia@yahoo.co.id \\ ${ }^{2)}$ School of Education Policy and Implementation \\ Victoria University of Wellington, New Zealand \\ and School of English Language and Letters, \\ Maulana Malik Ibrahim State Islamic University, Indonesia \\ E-mail: r.wahyudi.vuw.nz@gmail.com
}

\begin{abstract}
This study analyses Indonesian stand-up comedy performances by three comedians, Raditya Dika, Ryan Adryandhi, and Abdel Achrian. Assuming that the stand-up comedy's opening and ending are the crucial part besides the jokes telling itself, the present study tries to investigate the pattern of their opening and closing compared with the Rutter's (1997) pattern known in British stand-up comedian. Basically, stand-up comedy is similar with common conversation since it involves two participants, the comedian and the audience. The 153 lines of conversation are extracted from the videos are randomly collected from YouTube video site from 2011 to 2013. Conversation analysis on humor is the most appropriate framework to be used in the present study. As the result, the opening and closing indicate some similarities with the Rutter's pattern.
\end{abstract}

Keywords: Humor, Stand-up comedy, opening, closing, conversation analysis.

\begin{abstract}
Abstrak
Penelitian ini menganalisis pertunjukan komedi stand-up Indonesia oleh tiga komedian: Raditya Dika, Ryan Adryandhi, dan Abdel Achrian. Asumsi dari penelitian ini bahwa bagian pembukaan dan penutup dari pertunjukan komedi stand-up adalah bagian penting di samping leluconnya sendiri.Oleh karenanya, penelitian ini mencoba untuk menyelidiki pola pembukaan dan penutup dibandingkan dengan pola Rutter (1997) yang terkenal sebagai komedian stand-up Inggris. Pada prinsipnya, sebuah komedi stand-up setara dengan percakapan umum karena melibatkan dua peserta: komedian dan penonton. 153 baris percakapan yang diambil dari video secara acak dikumpulkan dari situs video YouTube dari 2011 hingga 2013. Analisis Percakapan pada humor adalah kerangka paling tepat untuk digunakan dalam penelitian ini. Hasil penelitian menunjukkan bahwa pola pembukaan dan penutup mirip dengan pola Rutter.
\end{abstract}

Kata-kata kunci: humor, komedi stand-up, pembukaan, penutup, analisis percakapan. 


\section{INTRODUCTION}

Stand-up comedy has become a part of popular culture in Europe and America since the earliest $18^{\text {th }}$ century (Mintz, 1985). Comedy has become a crucial part of social culture since long time ago but in different style especially in Indonesia. Ludruk and Ketoprak are the examples of comedy tradition in Indonesia.Van (1822) in Bayu (2012) found that Ludruk is a dance equipped with comical stories played by male comedians who pretend to be women. In Indonesia, stand-up comedy style has begun to be a part of popular culture only since several years ago after young comedians like Raditya Dika and Pandji Pragiwaksono use this style, although this style itself has been introduced several years before.

Stand-up comedy description is an encounter of a standing and single performer behaving comically and/or saying funny to the audience without properties support like costume, setting and other dramatic vehicle (Mintz, 1985). The motives and function of stand-up comedy are complex, ambigous and to some extent paradoxical (Mintz, 1985). Some of the topics usually used by comics are about ideology, politic, ethnic and other popular issues. Because of the limitation of properties, stand-up comedians use some performative techniques to engage the audience and elicit laughter (Glick, 2007).

Some previous studies are focused on the audience response, the performative techniques and their socio-political functions in the same manner as Glick (2007). The performative techniques based on the background knowledge of the audience are proposed by Glick (2007). He found that the comic make a particular order to make the audience come to his ideas easier, unconsciously unavoidable, for the American audience to accept the overarching analogical argument about Colonialism by Britain to India and America ideology-politic to Native America.

The previous studies which are related with particular ethnics on humor also already conducted by Hill \& Brandon (2002), Dimichele (2010), and Pếrez (2013). Hill \& Brandon examine the work of the stand-up comedian as a cultural mediator to integrate and understand the ethnic humor and the future of intercultural interaction. Dimichele (2010) with his research on Christian stand-up comedian and the humor found that the Christian stand-up comedian usually insert the religious element to their jokes. Pêrez (2013) find the distinction between white and non-white comedy students as they learn to engage the color-blind society through racial discourse. It is that the attention of that kind of society can be drawn through humor which is applicable to every kind of discourse.

The study focused on audience responses are conducted by Mcllvenny et al (1993) and Lockyers \& Myers (2011). The humorous message is usually packaged in two half: the first half, which often occurs at lulls in the show, elicits the audience response to the reference, while the second half launches into humorous message bouncing off the wealth of knowledge available with the category which has now been affiliated by a section of the audience (McIlvenny et al, 1993).While, according to Lockyers \& Myers (2011), the aims or motivations of the audience attending a stand-up performance are different. They are based 
on the types of stand-up comedy and/or particular stand-up comedians.

Some studies about humor in various media are conducted by Schulman (1994), McRury (2012), and Dynel (2013). Schulman (1994) find that African American stand-up style with its strong characteristics like "bawdiness and bravado", is to resist the status quo and their special expression. In another study conducted by McRury (2012), stand-up comedy can work as therapeutic of anxiety of society. Dynel (2013) tries to reveal some types of humor in dramatic discourse and associate it into incongruity and superiority theory. Incongruity theory which is actually to show the deviation of cognitive model of reference reveals some types of humor to show aggression, they are "disparaging conversational humor" ( $p$. 24)and "impoliteness" (p. 34). While, superiority theory is "the enhancement of one individual over another is the driving force of disparaging humour in film talk, where the focus is on the speaker's wit and intellectual victory over other interactants" (p. 53).

Furthermore, humor research commonly discussed the 'sequence of jokes' and how the interactional involvement between the comedian and audience developed (Rutter, 2000). Schegloff (1968) in Scarpetta \&Spagnolli (2009) said that "A person who seeks to engage in an activity that requires the collaborativework of two parties, must first establish, via some interactional procedure, that another party is available to collaborate" (p. 6). Thus, an opening and then ending must be the important part of a stand-up comedy. Specifically, this paper will present the structures of opening and ending that regularly enough to be used in Indonesia. Since stand-up Comedy has limited time, the opening and the closing act must be as attractive and effective as possible in order to deliver its actual purpose. Finally, it will suggest the rule, structure and perhaps ethnicity aspects of the Indonesian comedian performance.

Hence, considering the field which has not studied yet, the present study try to answer two questions below.

a. How do Indonesian Stand-up Comedians start and end their show?

b. What is the pattern of the opening and closing in Indonesia Stand-up Comedy?

Atkinson, et al (1978 citedin Rutter, 1997) explains that like conversation, stand-up is a "collaborative production" ( $\mathrm{p}$. 92). That it is not only oriented to the stand-up comedian, but also to the people who are attending the show and the focus is the interaction between them. Furthermore, he also claims that as live interaction, stand-up and audience laughter, like talk in natural conversation, is "structured and ordered" (p. 112). Schegloff and Sacks (1999) also proposed two basic features of conversation: "(1) at least, and no more than, one party speaks at a time in a single conversation and (2) speaker change recurs" (pp. 71-72). However, the "speaker change recurs" event in stand-up comedy happens when the audience respond to the audience's joke, it is not only laughter, but also applause.

Since stand-up comedy is similar to natural conversation, the appropriate method to study this kind of comedy is Conversation Analysis (CA) using Jefferson and Markee (2000) transcription. The term Conversation Analysis has been used to describe work that is informed by a broad range of disciplinary perspectives, 
including pragmatics, speech act theory, interactional sociolinguistics, ethno methodology, the ethnography of communication, variation analysis, communication theory, and social psychology (Schiffrin, 1991) stated in Markee. Paltridge (2006) states that CA as the description below:

"Conversation Analysis is an approach to the analysis of spoken discourse that looks at the way in which people manage their everyday conversational interactions. It examines how spoken discourse is organized and develops as speakers carry out these interactions. Conversation analysis has examined aspects of spoken discourse such as sequences of related utterances (adjacency pairs) preferences for particular combinations of utterences (preference organization), turn taking, feedback, repair, conversational openings and closings, discourse markers and response tokens. Conversation analysis works with recordings of spoken data and carries out careful and fine-grained analyses of this data" (p. 107)

CA is not only useful in analyzing audio or video recording but also its transcription (Rutter, 1997). Conversation Analysis assumed by Rutter (1997) as the best method in order to investigating standup comedy. It is because the previous studies which are conducted on the psychological, biographical, or the fusion of performance and audience aspect, are fail to establish the suitable analytical and methodological tools. Although it attempts to develop a systematization features of stand-up performance, it does not address any issues surrounding how an audience act or react to the performance, which cause the lack of exploration of live relationship between performer and audience. Finally, it fails to answer the important role of audience in the stand-up performance. It establishes the assumption that efficient delivery of a joke by a standup comedian will necessarily produce the expected laughter of the audience.

Basically, stand-up comedy is quite simple comedy since it does not need any costume or other devices. Glick (2007) explains"a lone comedian stands on a stage with a microphone and talks to an audience that has paid to be present". As the opening, the comedian then discussing about the background, life-style, and some attitudes and beliefs which make the audience accept the comedian's 'marginal status' and establish it with applause and laughter, thereby establishing a tone of gaiety and fun (Mintz, 1985) which marks that the comedy routine can begin. On the other hand, the closing after the successful jokes will be very important since it informs the audience that the jokes are already done.

In conventional stand-up comedy, (Rutter, 1997) proposed seven moves which can be identified potentially present in the start of an act:

- Compere's Introduction: in which prior to the entrance of the comedian they are introduced to the audience by compere.

- Audience Applause which accompanies the departure of the compere and welcomes the stand-up onto the stage

- Greeting of Audience by comedian

- Comment on the Setting in which the stand-up makes comment on one of four locally specific areas: the audience, the venue, their own act or meta-comment on the act.

- Request for Action where the comedian asks the audience to perform a specific act as a group

- Response to Request by audience during which the audience comply with the comedian's request

- First Canned Joke or the final move in the opening sequence in which the stand- 
up begins their routine proper by delivering the first of their pre-scripted humorous sequences. This can be seen as paralleling Schegloff's first topic ( $\mathrm{p}$. 145).

As the reaction of the audience, the other kind of responses may be produced including laughter, applause, whistling, booing, heckling, and other verbal comments such as disgusted "erhhs!" or affilitiative "Yeahs (Rutter, 1997). To start or open the shows, comedians have their own characteristics. The opening of an encounter is the start of the interaction, namely the place where mutual attention, availability, and willingness to engage in a specific kind of interaction are established (Scrapetta \& Spagnolli, 2009).

Schwarz (2010) divides joke techniques in stand-up comedy into four classifications. The classifications are; Paralanguage (intonation and body language), Ridicule (display impoliteness and aggressiveness), Satire (make fun of people superior to oneself), Power, Solidarity and Politeness. Then, she also classifies the figurative language in standup comedy; Wordplay, Puns, Ambiguity, Implication and Allusion. Beside joke technique and figurative language which are used in stand-up comedy, Schwarz also divides some figurative language such as Repetition, Formulaicity, Disfluencies, Pauses, False starts, and Discourse Markers.

\section{METHOD}

The three videos of Indonesian standup comedy shows are downloaded from Stand-up YouTube site (http://www.youtube.com/) utilizing Youtube Downloader, software to download videos from YouTube.

The 153 lines of transcription is resulted from the excerpts of the opening and ending of the show. They are extracted from three shows performed by every comedians, which are randomly chosen from the website. The stretches of the time of the performance is from 2011 to 2013,

The present study exploits the Rutter's (1997) data analysis method. Before the analysis started, the data are collected from different sources and ways: one-off recordings which are done by himself, a single performer recordings with different audiences, and commercially available recordings of well-established performers. Utilizing CA methodology, Rutter can make a limitation in his analysis on joking, laughter, and stand-up comedy.

1. Studies the Impure

CA is able to see the impurity of actual talk between individuals.

2. Stresses the live context

The talk is more than an exchange of phonemes, words, or sentences but a specific, local and time bound experience. The primary data collection is always events that would have existed without the presence or intervention of the researcher.

3. Based on Mutual Knowledge

Parties in a conversation are held responsible for maintaining the smooth running of the interaction and accept this responsibility. Parties whether they talk, do not talk, or choose not to talk do so with a working knowledge of a set of common and accepted rules. Although interaction is ordered it is not preformed, that is although observable structures can be noted they are applied in real time by each of the parties to an interaction (p. 94).

As the part of the data analysis, the exploration of the interaction between performer and audience to gain insight into the styles, techniques and methods which convert an unfit text into a successful 
stand-up performance. The next steps which are shown by Rutter are demonstrate that the laughter of audiences who are watching stand-up comedy is arranged into recognizable patterns and show that meaningful interaction and negotiation takes place between audience and performer and among members of an audience.

Put more attention to the routine way in which opening and closing acts are manufactured and how this is contributed to the audience and by the performer. Rutter (1997) also suggest ways in which the successful comedian uses rhetorical techniques to aid and support this negotiation and describe how these techniques are valued both by performer and audience. Then, it is continued with an analysis of joking and laughter based on a careful dissection of social interaction which challenges many of the presuppositions to earlier explorations of joking exchanges and constructs a new framework for understanding. This interactional focus will permit exploration of joking and laughter in naturally occurring exchanges between performer and audience.

The results of the careful investigation are the key to conclude the common features which are used in the opening and ending. The next step will be a comparison process with the Rutter's (1997) diagram on British stand-up performance. If there are some elements which have not shown yet, the final step is suggesting some new elements into the diagram.

\section{RESULTS AND DISCUSSION}

\section{Stand-up Opening}

Raditya Dika tends to use greetings related with time and self-introduction to start his jokes as shown in following Excerpts (1-3):
Excerpt 1

\begin{tabular}{|c|c|c|}
\hline 1 & Aud & $\mathrm{xxxx}=$ \\
\hline 2 & $\mathrm{RD}$ & $\begin{array}{l}=\text { Selamat malam teman } \\
\text { teman semuanya }\end{array}$ \\
\hline & Aud & $\begin{array}{l}\text { Good evening friends } \\
\text { (mala::m) } \\
\text { (evening) }\end{array}$ \\
\hline & $\mathrm{RD}$ & $\begin{array}{l}\text { a: Nama saya Raditya Dika. } \\
\text { a:: My name is Raditya } \\
\text { Dika }\end{array}$ \\
\hline & & $\begin{array}{l}\text { da:n saya hari ini akan= } \\
\text { and today I will }\end{array}$ \\
\hline & & $=$ mencoba untuk berbicara \\
\hline & & $\begin{array}{l}\text { tentang teman-teman, } \\
\text { try to talk about you all } \\
\text { kalian semиa } \uparrow\end{array}$ \\
\hline
\end{tabular}

The audience welcomes Raditya Dika by clapping before the comedian start to greet. Then, the comedian greets (line 2) as his very first word and is answered by audience without interruption. The comedian continues introduce himself (line 4), states his name and tries to illustrate the theme of his jokes (line 6). "Stand-up is judged by the audible response of the audience, it is a form which encourages and requires vocal input from the audience and as such, even at thisvery early stage in the act, it can be seen that the response to the greeting is very important to the comedian" (Rutter, 1997, 168). This is the most important role of opening and the audience's response, which shows that the comedian and audience's role is being understood, recognized, and accepted within the dialogue (Rutter, 1997). In doing so, Audience's respond toward Dika's greeting shows that the comedian and audience's role is being employed.

The similar sequence seems also used in another show of the second show, as in the excerpt below: 


\section{Excerpt 2}

8

12

$\mathrm{RD}$ (s)

$$
\text { Keep calm }
$$

Selamat malem temen

Good evening friends

Mungkin diantara kalian= perhaps there are among of you $=$ ada yang jadi followers gue $\downarrow$, who become my followers ada yang pernah baca buku gue juga. also who have read my book em: klo yang belum tau em: and if (you) have not know nama gue Raditya Dika[ gue penulis . my name is Raditya Dika, I am a writer

$$
\text { Aud [woo::hoo:hoo: xxx }
$$

$15 \quad \mathrm{RD} \quad$ santai $\left[\right.$ santai, ${ }^{\circ}$ santai $\downarrow$$$
\text { Aud [h-hhhhh-h }
$$

\section{Excerpt 3}

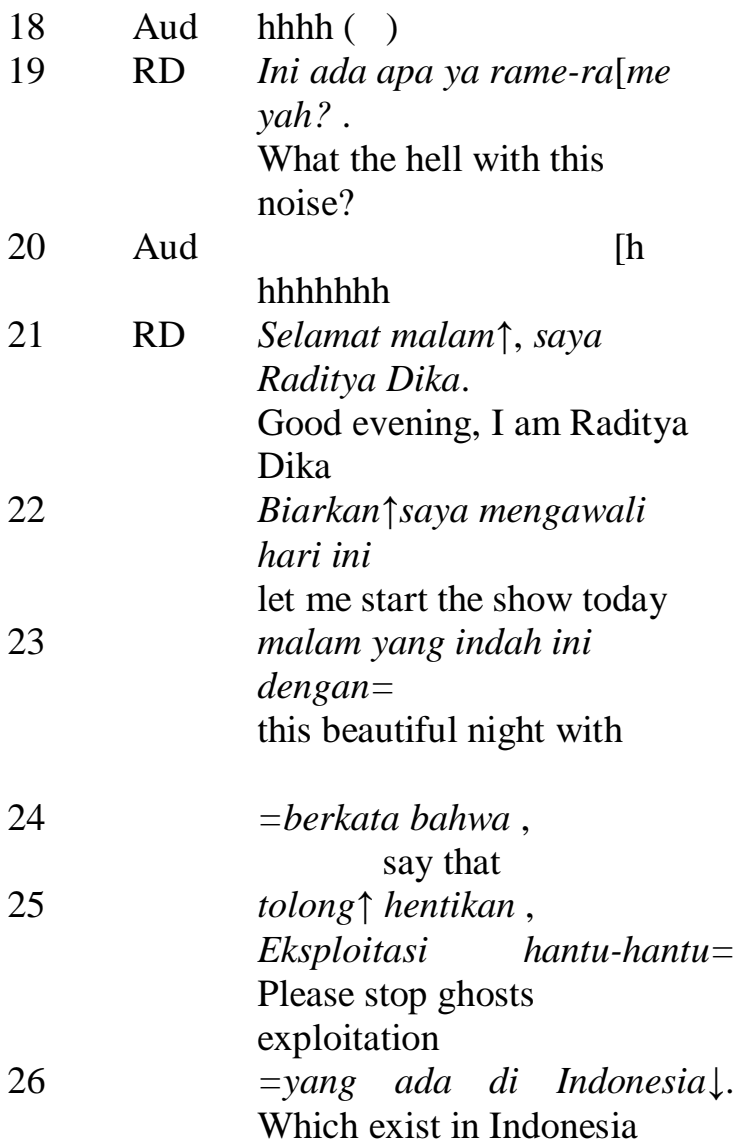

The third excerpt shows the similar pattern as in excerpt 1 and excerpt 2 where the comedian introduces his name first. However, before introducing his name, the comedian says something which is related to the condition of the audience. The audience is still brought from the previous event before the comedian's opening (line 18). Thus, Dika tries to calm them down and influence them be more focused on his shows by saying "ini ada apa ya ramerame, yah? -- What the hell with this noise?" (line 19). Instead of saying something about audience's background as in second excerpt, Dika chooses to introduce himself directly and continues to state the topic of his jokes. 
Even though Ryan also uses greeting at the very first time, he do not directly introduce himself, even he tries to communicate with the audience by talking about the condition or events that perhaps already known by both of stand-up comedian and audience, as shown in the excerpt 4-6 below.

\section{Excerpt 4}

RA Oke, selamat malam

semuanya $\uparrow:$

Okay, good evening

everybody

28 Aud Mala::::[::m

Evening

29 RA

[U::giiila $\mathrm{u}:$ : this is crazy

30 RA Gue denger-denger si

Boris=

I heard that Boris

$31=$ =abis stand-up disini,

yah?

have stand-up here, right?

32 RA Kerasa sih, emang aroma

mice nya beda

feel it, the mic's aroma is

different

33 Aud HНHНHНHНH [- $-\mathrm{H}-\mathrm{H}$

hhhhh

$34 \quad$ RA

$[\mathrm{Hmmm} \ldots$

kayak-

hmmm like pork with sauce

36 Aud [hhhhh-hhh

37 RA >Agak beda memang < somewhat different

The excerpt 4 is the transcription of different stand-up comedian. At the very first time, Ryan tries to catch audience's response by greet them (line 27) which is answered by the audience (line 28) and Ryan's comment on audience. "By making comment on specific features of the performance surroundings the performer reinforces the liveness of the stand-up act. By being not only topical but specific, the comedian's comments are marked not only as unique to the current performance but concerning" (Rutter, 1997). The interaction with the current audienceBefore he do his joking ritual, Ryan tries to communicate with the audience by talking something in common (line 30) and then make it as a racism joke by saying that me microphone's aroma is like "pork with sauce" (line 35). In Indonesia, pork is uncommon food, since the majority of the inhabitants are Moslem which do not eat pork. On the other hand, pork is usually eaten by people who are not Moslem especially the descendants of Tionghoa.

Discussing about Ethnic jokes, it is defined by Gonzales \& Wiseman (2005) as perceived behaviors, customs, personality, or any other traits of a group or its member by virtue of their specific sociocultural identity. The target of ethnic humor is usually the geographic, economic, or linguistic edge of the society culture. On the other hand, ethnic humor is more dominant in minority groups because their need for stronger social cohesion. In doing so, Ryan uses the ethnic jokes, with the custom of Tionghoa or Chinese group identity as the target since they are 
recognized as immigrant or not native inhabitant of Indonesia.

\section{Excerpt 5}

RA

Yak yak yak.

Okay okay okay

39

Assalamu'alaikum

Warahmatullahi

Wabarakatuh $\downarrow$

(Islamic Greeting)

$40 \quad$ Aud

[xxxxXXXXXXXXXxxxxx

41 Aud

$[\mathrm{Hu}::$ :

42 RA > Gue $\uparrow$ suka heran sama

iklan- iklan

I always surprised with

43

yang ada di Indonesia $\uparrow$

gitu<

the Indonesian ads.

As the excerpt 4, Ryan is also directly open his performance without introducing his name and greet the audience with Islamic greeting instead (line 39). After the audience's applause (line 40) and respond (line 41), Ryan directly introduce the very first jokes for the show.

\section{Excerpt 6}

44 RA Tepuk tangan dulu: untuk= Please, give applause

$45 \quad=$ Stand-up festival $\uparrow$, gila $=$ for stand-up festival

46 Aud $=$ XXXXXXX

47 RA Festival fer-perta $\uparrow \underline{m a}$ sebesar ini.

the first biggest festival

Similar with the previous excerpt, Ryan also do not introduce himself and ask the audience to appreciate the event they are in (line 45 and 47). Thus, Ryan tends to be straight forward in his shows without introducing himself in the very beginning of his shows.

While, another stand-up comedian, Abdel, seems also showing the ethnicity aspect in the very beginning phase. The excerpt 7-9 below will discuss about the openings by Abdel Achrian.

\section{Excerpt 7}

\section{AA Asssalamu'alaikum} ((Islamic Greeting))

Aud wa'alaikumsalaam $\mathrm{h}-\mathrm{h}-\mathrm{h}$ ((respond of Islamic

greeting))

AA Pemirsa selamat malam

(raise the right hand)

= Good evening, audience

51 AA Stand-up-comedy-showstand-up comedy show

$52 \quad$ AA Tepuk tangan dong.. = please, give applause

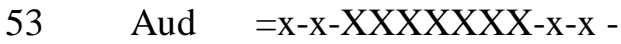

$54 \quad$ AA Masak harus disuruh udah pada [gede? Adults do not need command

$55 \quad$ Aud

[h-h-hhh

$56 \quad$ AA Yak, stand-up comedy show ini,e: 
yeah, this standup comedy

show

57 AA ini namanya neon-sign nya

nih.

This neon-sign

58 AA Apa:-apa ya namanya ya what's the name?

ini saya bawa sendiri

memang $\downarrow$ dari rumah $=\mathrm{I}$

brought it from my home

$60=$ karena tadi

because it was

61 Aud [h-hhhh

62 AA sebelum penampilan saya, before my performance it was not like this

ini masih belum be[gini

64 Aud [h-hh

65 AA Yak, saya emang udah I paid much moda:l, yeah,

66 jadi kalau saya ngomong, lucu nggak lucu so if I talk, whether funny

ornot

$67 \quad$ Ketawa aja na[nti ya. Just laugh

$68 \quad$ Aud

[H-H-hhh

Abdel tends to be more religious by greeting the audience with "Assalamu'alaikum" (line 18) or special greeting used by Moslem and then replied by the audience (line 49). Perhaps, the reason Abdel uses this kind of greeting to open his jokes is because he already got the

image as a presenter of a religious show in one of TV channel. The audience's laughter after their respond shows that the audience already got such ethnic or religious background knowledge. Thus, utilizing this image will activate audience's background knowledge to mark that the comedian and audience start working together and the comedian can continue his jokes

In the "constructing liveness" or a way of establishing uniqueness of a particular performance (Rutter, 1997, 174), Abdel tries to leads the audience by setting up the opening with discussing something that both of the audience and comedian know, that is the background of the stage that he call it neon-sign. Differs with Dika and Ryan, Abdel tends to enlongate his construction of liveness, before the real joke. He told that he already paid much by borrowing the neon sign (line 57-59), thus with this reason, he asked the audience to laugh every time he tells jokes whether or not it is funny. The request of action which is done it this part shows that the opening has not done or the main jokes have not started yet. However, even though Abdel tries to enlongate his pre-jokes, it does not draw too much audience's laughter. Proven with only short and not too loud laughter as the joke ends (line 68).

69

70

71

72

\section{Excerpt 8}

Aud XXXXXX

Aud ((chatter $))$

AA gue sebenernya gak suka:

$p i \downarrow n k=$

Actually I don't like pink

$=$ Gue lebih suka merah

muda-

I prefer bright red 
bahasa \& sastra, Vol. 14, No.2, Oktober 2014

\begin{tabular}{|c|c|c|}
\hline 73 & Aud & (...) Н-Н-ННННННН \\
\hline 74 & Abd & $\begin{array}{l}\text { Maap, Eyang Subur= } \\
\text { I'm sorry, Subur Granny }\end{array}$ \\
\hline 75 & & $\begin{array}{l}=\text { Lo jadi subur gara } \\
\text { gara= } \\
\text { You become subur (fertile) }\end{array}$ \\
\hline 76 & becaus & $\begin{array}{l}\text { =Eyang Pupuk } \\
\text { e of Fertilizer Granny }\end{array}$ \\
\hline 77 & Aud & H-Hhhhhhh \\
\hline 78 & AA & $\begin{array}{l}\text { sama eyang ge } \uparrow m b u r \\
\text { And Loose Granny }\end{array}$ \\
\hline 79 & Aud & hhhhhh-h-h \\
\hline 80 & $\mathrm{AA}$ & $\begin{array}{l}\text { Selamat Mala } \uparrow m \\
\text { good evening }\end{array}$ \\
\hline 81 & Aud & $\begin{array}{l}\text { Mala:: } m \\
\text { evening }\end{array}$ \\
\hline
\end{tabular}

The excerpt 8 above also shows the characteristics of Abdel's opening, which is tend to be extended. Similar with the excerpt 8 , the extension of the opening is started from everything around the comedian, such as the color of the shirt (line 71 and 72). And then relate it with the current issue about Eyang Subur, before finally "officially" open his performance by saying "good evening" (80).

\section{Excerpt 9}

\begin{tabular}{|c|c|c|}
\hline 82 & $\mathrm{AA}$ & $\begin{array}{l}\text { Sela } \uparrow \text { mat malam } \downarrow \\
\text { Good Evening }\end{array}$ \\
\hline 83 & Aud & $\begin{array}{l}\text { mala:m (low voice) } \\
\text { Evening }\end{array}$ \\
\hline 84 & $\mathrm{AA}$ & $\begin{array}{l}\text { Kurang keras, Sela } \text { mat } \\
\text { Malam! } \\
\text { Louder, please! Good }\end{array}$ \\
\hline 85 & Aud & $\begin{array}{l}M A L A:: M \\
\text { Evening }\end{array}$ \\
\hline
\end{tabular}

86 AA Nggak, saya yang kurang keras $=$

No, I'm the one who must

be louder

87

=Itu udah cukup keras yak

(point at one side)

that's loud enough

$88 \quad$ AA Sela $\uparrow$ mat Malam!

The excerpt above also shows the characteristic of Abdel's opening where he always make jokes toward something around the place where the show happens. The very first greeting (line 82) is actually to attract the audience. After the audience's response which is in low voice means that the very first greeting do not draw too much attention. Thus, Abdel make it as a joke with a comment on the audience's response and then repeat the greeting once more (line 84). However, after the audience's loud response, he makes it as a joke by saying that the one who have to be louder is himself (line 86). The 'real' opening or greeting is started after that, with a greeting once more (line 88 ).

As the conclusion of stand-up opening where the interaction between the comedian and the audience is set up, greeting the audience is commonly used in the first time to start the performance. After knowing audience respond toward the action, thus the comedian can continue to the pre-jokes or the topic of the jokes which will be delivered. Actually, the structure of opening which is used by Indonesian comedian is not far from the structure of British comedian, as Rutter (1997) conclude the structure of opening into a diagram (cropped because of different start, one of these orderings may be absent from the sequence) 


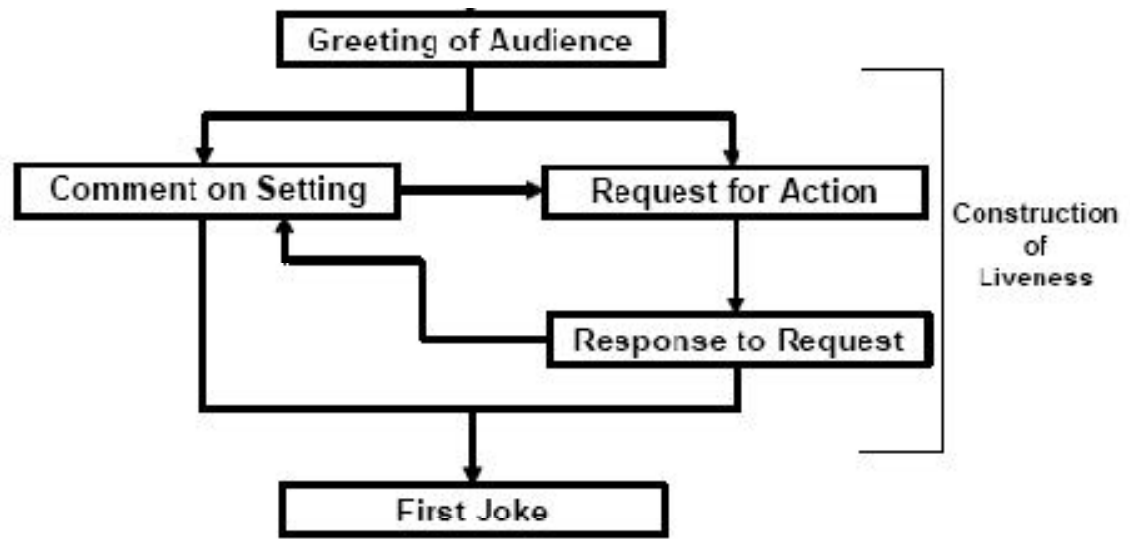

Figure 1. Rutter's $(1997,189)$ Opening Diagram

\section{Stand-up Closing}

Closing or "not a place for new materials" (Schegloff and Sacks, 1997, p. 93) can be the most crucial part of the stand-up comedy since the comedian usually do not have much time to deal with it. Thus, as the alternative, they will close it suddenly without too much sign to the audience. Rutter (1997) stated that the order of stand-up closings are tend to be similar and without much deviation and repetition. He also classifies the stand-up closing order to be pre-closing (a final humorous sequence), audience laughter (marks the commencement of the closing proper), comment on audience (commenting on their quality or making a locally specific observation), reintroduction (repeats the name by which they were introduced), appreciation (thank the audience), exclamatory closing, audience's applause, and compere's outro (he first turn taken by the compere after the comedian's exit). The closing section may contain a "terminal exchange" (p. 94) and accomplish a proper closing (Schegloff \& Sacks, 1997).
The closing by Raditya Dika below will show how the stand-up closing is suddenly done.

Excerpt 10

89 RD Dia bilang "kok kenceng banget?"

She said "why is it too tight?"

$90>$ >Gak [apa-apa, gak apa apa<

“it's all right, it's all right

Aud

[HHHHHHHHHH

92 KITA BA[KAL MATI::" WE ARE GOING TO DIE

Aud

$[\mathrm{HHHH}[\mathrm{HHHH}$

94 Aud

[X-X-X-X

95 RD nama gue Raditya Dika, = My name is Raditya Dika 96 thank you, good evening

The excerpt above shows that Dika does not tell that his show will be ended directly. In usual conversation, Schegloff \& Sacks (1999) offer the systematic order in conversation where there are some utterance before the real closing of the conversation or it called 'pre-closing'. 
They proposed the indications of preclosing, "occupy the floor for a speaker's turn without using it to produce either topically coherent utterance or the initiation of a new topic" (p. 80). After the pre-closing of the stand-up show ends (line 92), Dika gives a chance to audience laughter and responds (line 93 and 94). Instead of giving sign that his jokes will be ended, Dika prefer to do re-introduction (line 95), which is continued with appreciation and the last is exclamatory closing (line 96).

\section{Excerpt 11}

97

RD Alay itu proses menuju dewasa, $a l a y^{l}$ is a progress to be mature

98 skema manusia Indonesia, schema of Indonesian

99 lahir, bayi , balita, remaja , be borned, baby, under five, teen

$100 \quad$ ala::y, dewa sa.

alay, adult

101 Aud hhHHH[HHHHhhhh

102 Aud $[\mathrm{x}-\mathrm{x}-\mathrm{x}-\mathrm{x}$

$103 \mathrm{RD}>$ Terima kasih na[ma gue

Raditya Dika

thank you, my name is

Raditya Dika

104 Aud

[wo::::ho::::::: XXXXX

$105 \mathrm{RD}$ selamat malam $<=$

106 good evening $=\mathrm{XXXXXXXXX}$

The similar pattern happens in another Dika's show. The last joke is ended before the audience laughter and responds (line 101 and 102). Then, he continues with appreciation (line 103) before re-introduction (line 103) and ended with exclamatory closing "selamat malam" (line 105)

Excerpt 12

RD $\quad:$ ini hari yang apa
namanya=
e: this is what's day
=hari yang baik banget
a good day
buat stand-up comedy,
to have stand-up
comedy
gue suka banget $\uparrow$ sama
(hipe)
I love (hipe)
sama yang sudah ada
sekarang ini $\downarrow$
which is available now
(Alhamdulillah)
(Moga) tetap terjaga ya=
I hope it will last forever
=XXXXXXX
karena gue masih inget
banget=
because I still remember
=pertama-tama gue stand
up $\uparrow$ waktu itu
the first time I had stand-up
[show]
gue nyoba pas lagi talk show,
I try when I am having talk
show
yang dating cuma 5 orang.
the comers are only five
people
tapi >lo ternyata tau
nggak?
but don't you know?
ternyata lima orang $\uparrow$ itu
those five people
kemana-mana gue stand-up,
mereka ngikut=
everywhere I have stand-up,
they're always there
=jadi gue udah punya
pendengar setia $\downarrow$
so I already have loyal




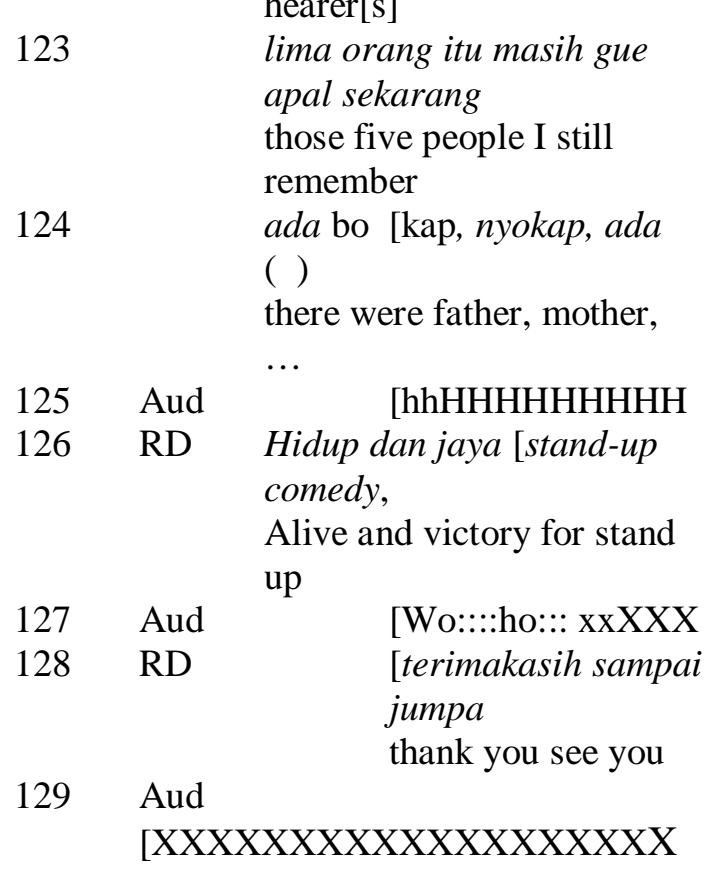

Dika gives some signs that his standup comedy will be ended. Before do the pre-closing, he says something about the audience (line 110). Then, he continues it with the last joke (line 124). After audience laughter happens, he does exclamatory (line 126) and closes it with appreciation and another exclamatory (line 128).

In the excerpt above, Dika comments on audience that actually to lead the audience to his last joke. He appreciates how crowded the audience that makes him remember the first time he did stand-up comedy (line 116). The audience was only five people that make him remember them even until now. Audience laughter happens after he says that they are only his parents and siblings. We can assume that the comment on audience that Dika does, actually is multifunction. The first function is to calm down the audience after his previous jokes. The second function is pragmatically to tell the audience that his jokes will be ended soon. However, he does it to lead the audience to his last joke, and finally to the stand-up closing
The excerpt 13-15 below shows the closing by Ryan:

\section{Excerpt 13}

130

RA Itu artinya gue yang

paling jelek $d i=$ means I' $m$ the ugliest

134

135

RA Terima kasih slamat

=geng gue

in my group

Aud HHHHHH

RA Terima kasih,

sekian $=$

Thank you

$=$ dari Rian Adriandy= that's all fromRyan

malam $=$ thank you, good evening

Aud $=\mathrm{XXXXXX}$

Ryan closes his jokes after audience's loud laugh (line 132) and continue with gratitude by saying "thank you" (line 133) and state his name (line 134). However, he repeat the thanking action and added with greeting (line 135). Finally, it closes with audience's applause (line 136). It seems that this sequence is repeated in the excerpt 14 below.

Excerpt 14

137 Aud H-H-H-hhhhh

138 RA Terima kasih saya

Ryan Adryandhy

Thank you, I'm Ryan

139 Aud X-X-Xxxxxxxxxx 
Ryan appreciates the audience after the laughter of his last joke (line 137-138), and continue it with the re-introduction (line 138). Finally, it is closed with the audience's applause (line 139)

\section{Excerpt 15}

140 RA O.K. [stand-up fest, thank you,-

141 Aud [X-XXXXXXXXXX

142 Gue Ryan Adryandhy I'm Ryan

Terima kasih

Thank You

Similar characteristics of stand-up closing is also showed by Abdel in the excerpt below:

Excerpt 16

144 Aud HHHHH

146 AA Terima kasih, saya

Abdel Achrian=

Thank you, I'm Abdel

147 Aud XXXXX

Excerpt 17

148 AA Saya AbdelAchrian= I'm Abdel Achrian

$149=$ Terima kasih Thank you

150 Aud XXXXXXXX

\section{Excerpt 18}

151

\section{Aud H-HHHHHH}

AA Saya Abdel Achrian, terima kasih

I'm Abdel Achrian,

Thank You

\section{Aud XXXXX}

While Abdel closes the show by thanking and state his name or vice versa (line 146, 148-149, 152) after audience's last laughter (line 144, -, 151). At the last, it is closed with audience's applause (line 147, 150, 153). However, in his closing, Abdel does not use religious greeting as he used in the opening "Assalamu'alaikum". In Islam tradition, when someone open a conversation with salam (Islamic religious greeting) it should be closed with salam either, like "wassalamu'alaikum". Thus, the religious greeting by Abdel in the opening actually do not only have function as opening and identity marker, but also to activate audience's knowledge as his image of a presenter in a religious TV show.

The stand-up closing which usually done by Indonesian comedian is tend to be straight-forward. As Dika closes it with greeting, thanking and re-introduction, so do that with Ryan and Abdel. It seems that this structure is somewhat not different with Rutter's claim "similar and without much deviation and repetition". Finally, the structure of closing can be drawn as Rutter's. 
Figure 2: Rutter's (1997, 279) diagram on stand-up closing



However, since there are some elements which frequently used, the elements can be re-ordered like the diagram below, even though one of the element may be absent. The suggestion of a new construction is like the diagram below:

Figure 3: Recommended ClosingDiagram

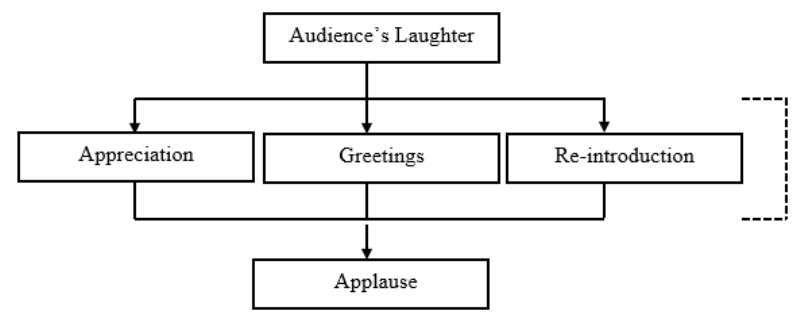

The diagram shows that after audience's last laughter, the comedian will close it with appreciation, greetings, or/and re-introduction. Finally, it is 'really' closed with audience's applause.

\section{CONCLUSION}

At the beginning of this paper, it is stated that opening and ending of a standup performance hold an important rolein order to deliver a successful humorperformance. Furthermore, the limitation of stand-up performance demands the comedians to greet the audience, telling jokes, and then thanking the audience in the simplest way. Besides limited in the matter of time, stand-up comedy also limited in the matter of properties. Thus, it can be said that microphone is the lone property of standup performance.

The stand-up comedians try to start the jokes as soon as possible in order to catch the audience's attention. In doing so, standup comedians try to start their jokes as soon as possible without any exception even though it is already the opening part. There are some typical actions which usually done by the comedians before really start their jokes, such as "comment on action, request for action, and response to the request" which Rutter (1997) calls it construction of liveness. The structure of the opening according to Rutter is actually also employed by the Indonesian comedian since they also utilizing similar elements in doing the opening. First, the comedians start their act by greeting the audience, liveness will be constructed through local reference, and the first joke will be delivered.On the other hand, as the Exclamatory part when the comedian try to start jokes, stand-up opening is also a potential area to do racist or ethnic jokes, like what Ryan and Abdel already done.

Three comedians above have similar exclamatory closing as Rutter (1997) suggests. The comedian will close it with appreciation, greetings, or/and reintroduction, and 'really' closed it with audience's applause. Specifically,two of the comedians tend to use ethnical identity such as salam, even though it is not properly used during the opening and closing. However, this research do not have capacity to the further ethnical identification.Finally, studies about audience of stand-up comedy performance 
and its context, and the ethnical identification especially in Indonesia can be a considerablestudy in the future.

\section{ACKNOWLEDGMENTS}

We would like to express our sincere gratitude to journal Bahasa \& Sastra for publishing this article.

\section{REFERENCES}

Akin, A. (2013). The interactional context of humor in Nigerian stand-up comedy. International Pragmatics Association, 23(1), 122.

Dika, R. (n.d, May 23). Raditya Dika (author of Kambing Jantan. Viewed 23 May 2013.

http://www.goodreads.com/autho r/show/600490.Raditya_Dika

Dika. (2013). Siapa sih, Radith?. Viewed 23 May 2013. Retrieved from: http://radityadika.com

Dimichele, A. (2010). Serving the Lord with gladness: Situating Christian humor in three historical contexts (Thesis). North Carolina: Wake forest University.

Dynel, M. (2013). Humorous phenomena in dramatic discourse. European Journal of Humor Research, 2260.

Scarpetta, F.\& Spagnolli, A. (2009). The Interactional context of humor in. Research on Language and Social,42:3, 210-230. DOI: $10.1080 / 08351810903089159$

Glick, J. (2007). Some performative techniques of stand-up comedy: An exercise in the textuality of temporalization. Language \& Communication, 27, 291-306.
Gonzales, E \& Wiseman, R. (2005). Ethnic identification and the perceived humor and rudeness of ethnic jokes. Intercultural Communication Studies, 16(2), 170-183.

Hill, L. \& Fitzegerald (2002). Humor reconsidered with prospect in interethnic relations. Intercultural Communication Studies. 6(4).

Jefferson, G. (1985). Glossary of transcript symbols with an introduction. In Lerner, G. (Ed.) Conversation analysis: Studies from the first generation (pp. 13-31). Amsterdam / Philadelphia: John Benjamins Company Publishing.

Knoedelseder, W. (2009). I'm dying up here: Heartbreak and high times in stand-up comedy golden era. New York: PublicAffairs.

Krismantari, I. (2013). Ryan Adriandhy: Taking comedy seriously. Retrieved from http://www.thejakartapost.com/ne ws/2011/12/29/ryan-adriandhytaking-comedy-seriously0.html 18 December 2013

Lockyer, S. \& Myers , L. (2011). 'It's about expecting the unexpected': Live stand- up comedy from the audiences' perspective. Journal of Audience and Reception Studies, 8(2).

Markee, N. (2000). Conversation analysis: Second language acquisition research: Theoritical and methodological issues. London: Lawrence Erlbaum.

Mazeland, H. (2006). Conversation analysis. Encyclopedia of 
Language and Linguistics, 3 , 153-162. Retrieved from http://www.let.rug.nl/mazeland/bi bsel08.htm

Mintz, L. E. (1985). Standup comedy as social and cultural mediation. American Quarterly, 37(1),7180.

McIlvenny, P., Mettovaara, S., \& Tapio, R.(1993). Stand-up comedy and audience response. Accessed from http://paulserver.humfak.auc.dk/r esearch/cv/Pubs/stand-up93.pdf 11 March 2014

McRury, I. (2012). Humour as 'social dreaming': Stand-up comedy as therapeutic performance. Psychoanalysis, Culture \& Society, 17(2), 185-203.

Paltridge, B. (2006). Discouse analysis. London: Continuum.

Pếrez, R. (2013) Learning to make racism funny in the 'color-blind' era: Stand-up comedy students, performance strategies, and the (re)production of racist jokes in publics. Discourse Society, 24(4), 478-503.

Rutter, J. (1997). Stand-up as interaction: Performance and audience in comedy Venues. University of Salford. Unpublished dissertation.

Rutter, J. (2000). The stand-up introduction sequence: Comparing comedy compères. Journal of Pragmatics, 32 .

Russell, D. (2002). Self-deprecatory humour and the female comic: Self-destruction or comedic construction? Thirdspace: A Journal of Feminist Theory \& Culture, 2(1).

Scarpetta, F.\& Spagnolli, A. (2009). The interactional context of humor in. Research on Language and Social, 210-230.

Schegloff, E. A. \& Sacks, H. (1999). Opening up closings. In Jaworski, A. \& Coupland, N. (Eds.), The discourse reader (p. 263-274). London and New York : Routledge.

Schulman, N. (1994). The house that black built: Television stand-up comedy as minor discourse. Journal of Popular film \& Television, 22(3), 108.

Schwarz, J. (2010) Linguistic aspects of verbal humor in stand-up comedy. Ph.D. University of Saarland. Unpublished dissertation.

Yule, George (2006). The study of language. Cambridge: Cambridge University Press.

Willis, Ken (2002). Making sense of humor: Some Pragmatics and political aspects .London Metropolitan University. Unpublished dissertation.

\section{End-notes:}

1 "Alay (Anak Layangan or Anak Lebay) is a pop culture phenomenon in Indonesia. It is a stereotype describing something "tacky" and "cheesy". The Alay culture phenomena spans over a wide array of styles in music, dress, and messaging. It has often been compared to that of 
the Jejemon phenomenon originating from the Philippines. Although, the former emerged much later and the latter was even admired in the west" (wikipedia.org)

\section{Transcription Guide}

The transcription system of this paper is adapted from Jefferson (2004) and Mazeland (2006) in Conversation Analysis. However, some modifications has arranged since the transcription is actually in Indonesian and translated into Standard English. The transcription system is summarized and described in details below:

RD, RA, AA Utterances said by Raditya Dika, Ryan Adryandhy, and Abdel Achrian

Aud Audience's reaction

$1,2 \quad$ numbering in all lines so that they easily can be referred

to the text.

Text Indonesian language

$:: \quad$ Colons indicate prolongation of the immediately prior sound. The longer the colon row, the longer the prolongation.

- $\quad$ An abrupt breaking off the word begun

$=\quad$ Equal signs indicate no break or gap. A pair of equal signs, one at the end of one line and one at the beginning of a next, indicate no break between the two lines. Underscoring indicates some form of stress, via pitch and/or amplitude. A short underscore indicates lighter stress than does a long underscore.

$\uparrow \downarrow \quad$ Arrows indicate shifts into especially high or low pitch.

${ }^{\circ}$ low ${ }^{\circ} \quad$ Degree signs bracketing an utterance or utterance-part indicates that the sounds are softer than the surrounding talk.

$\mathrm{h} \quad$ An intake of breath. The symbol proceed by a dot denotes an audible breath out.

$>$ faster $<\quad$ Right/left carats bracketing an utterance or utterance-part indicate that the bracketed material is speeded up, compared to the surrounding talk.

<slower> Left/right carats bracketing an utterance or utterance-part indicate that the bracketed material is slowed down, compared to the surrounding talk

LOUD Upper case indicates especially loud sounds relative to the surrounding talk.

$=\quad$ An instance in which the talk of one speaker leads into the speech of another without any pause.

.,? $\quad$ Punctuation markers are used to indicate 'the usual' intonation.

(text) Parenthesized ' $h$ ' indicates plosiveness. This can be associated with laughter, crying, breathlessness, etc.

( ) Empty parentheses indicate that the transcriber was unable to get what was said. The length of the parenthesized space reflects the length of the un-gotten talk.

((text)) Doubled parentheses contain transcriber's descriptions.

[ A left bracket indicates the point of overlap onset (the currently-used alternative to the double obliques)

] Arightbracket indicates the point at which two overlapping utterances end, if they end simultaneously, or the point at which one of them ends in the course of the other.

A group of laughter transcription is adapted from Rutter (2000) and audience applause at political speeches which are adapted from Clayman $(1992,1993)$ 
bahasa \& sastra, Vol. 14, No.2, Oktober 2014

hhhh Quiet audience laughter

$\mathrm{HHHH} \quad$ Loud audience laughter

$-\mathrm{h}-\mathrm{h}$

Quiet isolated laughter from individual in the audience

$-\mathrm{H}-\mathrm{H}$

Loud isolated laughter from individual in the audience

$\mathrm{XXX}$

Applause

XXX A rise volume of applause 